\title{
Supervision on Transference and Counter-Transference Issues for Undergraduate Students' Counseling Practice at Counseling Department
}

\author{
Amirah Diniaty \\ Counseling Department, Faculty of Education and Teacher Training, \\ UIN Suska Riau, Indonesia \\ E-mail: amirah.diniaty@gmail.com \\ DOI: http://dx.doi.org/10.15548/jt.v21 i2.88
}

\begin{abstract}
Undergraduate students should take 4 credits for counseling practice subject in Counseling Department of State Islamic University of Riau. The subject is taken by seventh semester students who conduct counseling practice at senior high school for 3 months. Based on prelimenary study, majority of students acknowledged that they felt nervous to follow this programme. Thus, the problem of transference and counter transference issue for undergraduate students counseling practice must be answered by their supervisions. The result showed that a total of $93 \%$ of respondents had positive transference, while $7 \%$ of them had negative one. It means that majority of respondents felt positive transference, while internship students faced identification counter transference. It was proved that internship students did not need to have negative thinking of being rejected by the schools. The finding also showed that $97.3 \%$ of interenship students faced identification counter transference, while $2,7 \%$ of them experienced for unidentification of transfenece. It means that there were a few of them should be supervised to have good counter transference. Supervision format that done by supervisor (university teacher) and tutor (high school teacher) was by conducting monthly meeting and by following up counseling result and writing report. It is recommended that a professional discussion is conducted to discuss problems faced by internship students.
\end{abstract}

Keywords: Supervision, transference, counter transference, counseling practice, individual counseling

\section{INTRODUCTION}

The success of counseling depends on the cooperation between counselor and client (Kottler, Sexton \&Whiston, 1994; Okun and Kantrowits, 2008 in Samuel Gladding, 2012). They have to collaborate in overcoming transference and counter-transference issues which occur in previous situation and present situation (Gelso \& Carter, 1985 in Samuel Gladding 2012).

Transference is projection of client's feeling, attitude, or desire towards counselor, in the past or in the present (Brammer et al., 1998 Brammer \& Mac Donald, 2003). On other hands, Lawrence (1982) said transference is the term refers to any feeling expressed or felt by the client toward the therapist, whether a rational reaction to the personality of the therapist or a projection of earlier attitudes and stereotypes. Cavanagh (1990) says that positive or negative transference is a form of resistance. Corey et al.(2007) find a therapeutic value in using transference.
According to Lawrence (1982), historically, transference means the process whereby client attitudes formerly expressed or felt toward another person that is important to the client were unconsciously "transferred" or projected to the counselor. For example, feelings of love, hate, ambivalence, or dependence at one time directed toward a patient are now irrationally repeated with the psychotherapist as the object. Rogers (1951) states that transference feelings develop when client perceives the other person understands her or him better than client understands herself or himself. The way of viewing transference, whether as hostility or dependency, depends largely on the degree of threat involved.

Irmo Marini (2009:296) notes that transference is not something that the client projects on to a blank-screen therapist but instead reflects the analyst's and client's intersubjectivity. Influenced by infant research, postmodern philosophy, relationally astute psychoanalytic forebears, and personal 
frustrations with rigidly "neutral" analysts, relational thinkers have accomplished a significant paradigm shift, widely dubbed the "relational turn" in psychoanalysis.

Transferences may be designated as positive or negative (Lawrence, 1982). A positive transference would be made by clients when they project their feelings of affection or dependency to the counselor, perhaps perceiving him or her as loving, helpful father or mother. A negative transference would be made by clients when they project their feeling of hostility and aggression. These transference feelings change form, sometimes quite suddenly. Often the client's positive transference will change to negative feelings when the counselor doesn't give all the reassurance or advice expected. The clients sometimes respond to the counselor in a manner similar to that used during childhood "confessions" to their real parents.

Otherwise, counter-transference leads to emotional reaction or counselor behavior that is projected toward his client that endanger, threaten, against or drain on counselor's resources (Fauth\&hayes, 2006). Lawrence (1982) views counter transference broadly to include conscious and unconscious attitudes of the counselor toward real or imagined client attitudes or overt behavior. It is the expression of the counselor's humanness. It may be simply a feeling of the moment which is a genuine response between two human beings; it also may be a form of counselor projection.

Counter transference can lead into negative effect on clients. Hadley and Sturpp (1976) summarized their views on negative effects of counseling around several time. All of these factors are counselor misjudgments or due to ignorance or rigidity of style. (1) Miss assessment of the background of the person (culture, meaning of psychopathology, motivation, ego strength, age factors) comes from pushing the client too fast or probing too deeply.(2) Applying the wrong techniques with particular client out of ignorance or unrealistic confidence allowing transference or counter transferences to get out of hand adding to the possibility of negative effect Communication difficulties and inability to recognize and to confront client cognitive distortions such as overgeneralization, add to probability of failure as a counselor. (4) Lack of a focal point or theme, where the counselor allows discussion of anything or focuses too narrowly, a factor in failure. (5) Mismatch of counselor and client, where the counselor is inflexible or blind to alternative theories of causation or methodologies of treatment is a contributing factor. (6) Ethical misconduct, where the counselor violates a confidence, holds the client too long in counseling, or lets the counseling process just drift, is an additional factor predicting failure of counseling.

Lawrence (1982) identified three sources of countertransference. The first category, the counselor's unresolved personal problems, and needs little explanation. The second category, situational pressure exist form of their feeling responsibility to see that the client improves, or feeling that their professional reputation is at stake if they fail with this client. The third source is communication or client feeling to the counselor. Gamsky and Farwell (1966) found that counselors reacted in a negative manner when the hostility was directed at them. Experienced counselor handled the hostility better than the less experienced. Corey (2007), classifies counter-transference into identification and dis-identification.

Transference and counter transference issue is interesting to be revealed on University Student counseling practice. According to undergraduate curriculum of Counseling Department of State Islamic University of Riau Indonesia, students take 4 credits for counseling practice subject. This subject is taken by students of seventh semester who do counseling practice at senior high school for 3 months. Students are nervous before coming to practice, especially during the training. They are afraid of being rejected during the practice at the school. 
The problem of transference and counter transference issue on University Student counseling practice must be answered by supervision. Supervision has been described as a means of transmitting skills and knowledge to all levels of counselors (Maki \&Delworth, $1995)$ by providing a continuous cycle of feedback, practice, and additional feedback via consistent assessment of strengths and areas for counselor improvement (Borders, 1991). Within professional counseling practice, supervision comprises both administrative and clinical aspects. Bernard and Goodyear (2004) provided:

Supervision is an intervention provided by a more senior member of a profession to a more junior member or members of that same profession. The relationship is evaluative, extends over time, and has the simultaneous purposes of enhancing the professional functioning of the more junior person(s), monitoring the quality of professional services offered to the clients that she, he, or they see, and serving as a gate-keeper for those who are to enter the particular profession. ( $p$. 8)

Maki and Delworth (1995) assert that supervision allows for enhancement of professional growth by providing education and consultation to developing professionals. It is also essential to note that, although professional growth is an important component to the supervisory relationship, client welfare and protection are of paramount value (Bernard \& Goodyear, 2004; Pearson, 2000).

\section{Supervision encompasses varying} formats depending upon supervisee and supervisor availability, needs, and preferences. These formats, discussed by Herbert (2004b), include self-supervision, individual or one-toone supervision, group supervision, and team supervision. Irmo Marini (2009) noted, with the exception of self-supervision where there is no external feedback provided to the counselor, beginning counselors should consider benefits and preferences when receiving supervision from one supervisor who either works in the same as (internal supervisor) or outside of (external supervisor) the counselor's work setting (i.e., one-to-one supervision).

In certain situations, supervision is provided to several counselors simultaneously by one or several supervisors. As a group, this format benefits individual members about issues that other counselors are confronting. This social-learning aspect may assist each counselor to expand in areas that could be potentially problematic in the future.

The disadvantage of this format is that it may not provide sufficient time and intensity that one-to-one supervision provides. Team supervision, which is a variation of group supervision, refers to supervision that usually occurs within the same work setting provided by a group of supervisors from various disciplines (e.g., within a junior high school setting).

Clinical Supervision for developing counselors deciding on which clinical supervision format is appropriate for each counselor depends on individual supervisee needs, employment setting resources, and availability of supervision. In addition, supervisor role and process may vary depending on the type of counseling services provided.

School counselors, mental health counselors, and rehabilitation counselors have distinct needs for supervision within their respective professional roles and counseling settings (Thielsen\& Leahy, 2001). Supervision in school counseling, for example, may focus more on administrative supervision or on program development supervision as opposed to clinical supervision (Roberts \& Borders, 1994) and may be more likely to occur as peer supervision (Page, 1994). However, supervision within mental health delineations of counseling will likely focus on clinical aspects of counseling (Magnuson, Norem, \& Wilcoxon, 2000). Conversely, supervision practices within rehabilitation counseling practice may vary widely depending on employment setting (i.e.public sector vocational rehabilitation, private for-profit proprietary rehabilitation) and may, as in school counseling settings, take a 
greater administrative or program evaluation focus (Herbert, 2004a).

Given various foci of clinical supervision within the professional disciplines, it is recommended that counselors seek supervision within their specific scope of practice. Counselors must also consult state regulatory boards to ensure that supervision is provided according to designated jurisdiction because some states require that supervisors be board approved prior to beginning supervision (Lum, 2007).

The aim of this research is to find out the description and the form of supervision in overcoming transference and counter transference issue on students who do the counseling practice. This result will take effect for sustainability of the counseling practice program in the future.

\section{METHOD}

This is a survey research. The survey was conducted on October 2013. This research tries to reveal the problems: (1) How is High School Students' transference attitude during the counseling practice of Counseling Department in their school? (2) How is the symptom of counter transference happening to the university students (internship students) during the counseling practice? (3) What are the forms of supervision that is given by tutors and supervisor in overcoming the counter transference which happens to internship students?

The subjects of the research are (1) 36 university students -internship students-, (10 males and 26 females) that belong to seventh semester of Counseling Dept which are trained on July to September 2013, They were required to do counseling at least for ten clients (students), (2) High School students, the clients of this counseling practice, 100 students (37 males and 63 females), and (3) 1 tutor from high school teacher and 1 from university.

\section{Instruments}

The data was collected by 2 closed questionnaires which consist of questions of transference symptom and counter-transference. These questionnaires got the data from the students who were clients of counseling. Clients are students who got counseling from university students- internship students- as subjects of the research.

There was a questionnaire about counter-transference which consists of questions identification and unidentification. This questionnaire will take data from internship students (from university). The respondent took by accident technique.

\section{Transference Symptom}

A 25-item of the transference symptom was next constructed, utilizing 1) items taken intact from positive 2) negative. The items for positive transference appearing on the 14-item by Table 1

\section{Table 1}

Positive Transference Symptoms

\begin{tabular}{r|l}
\hline No. & \multicolumn{1}{|c}{ Items } \\
\hline 01. & $\begin{array}{l}\text { See the counselor (internship students) } \\
\text { because they look like a lovely parent. }\end{array}$ \\
\hline 02. & $\begin{array}{l}\text { Make proud of the counselor } \\
\text { (internship students whom they } \\
\text { consult to in front of friends and other } \\
\text { teachers because of the service. }\end{array}$ \\
\hline 03. & $\begin{array}{l}\text { Imitate the internship students' } \\
\text { behavior because of their role as } \\
\text { counselor in everyday life whether it is } \\
\text { at school or at home. }\end{array}$ \\
\hline 04. & $\begin{array}{l}\text { The internship students who are their } \\
\text { counselor are idol. }\end{array}$ \\
\hline 05. & $\begin{array}{l}\text { Hope the internship students who are } \\
\text { their counselor present everyday. }\end{array}$ \\
\hline 06. & $\begin{array}{l}\text { Holds that internship students who are } \\
\text { their counselor are the expert in } \\
\text { counseling and careful like their } \\
\text { family. }\end{array}$ \\
\hline 07. & $\begin{array}{l}\text { Clients ask help from internship } \\
\text { students for personal problem they }\end{array}$ \\
\hline
\end{tabular}




\begin{tabular}{r|l}
\hline & have because they give credence. \\
\hline 08. & $\begin{array}{l}\text { When the problems are discussed } \\
\text { during the counseling with internship } \\
\text { students, client feels of being protected } \\
\text { and feels having solution. }\end{array}$ \\
\hline 09. & $\begin{array}{l}\text { Client asks for advice from internship } \\
\text { student whom they consult to for } \\
\text { solving their personal problem. }\end{array}$ \\
\hline 10. & $\begin{array}{l}\text { Clients share their joy to internship } \\
\text { students because of taking them as } \\
\text { brother or sister of other family } \\
\text { members. }\end{array}$ \\
\hline 11. & $\begin{array}{l}\text { They tell all their sad feeling to } \\
\text { internship students during the } \\
\text { counseling because they feel comfort } \\
\text { to. }\end{array}$ \\
\hline 12. & $\begin{array}{l}\text { Clients need the internship students as } \\
\text { their counselor to solve their personal } \\
\text { problem such as a need of younger } \\
\text { sister to the older sister. }\end{array}$ \\
\hline 13. & $\begin{array}{l}\text { Clients feel happy if the internships } \\
\text { students touch them such as at the } \\
\text { shoulder, head, so they feel comfort } \\
\text { and stable during the counseling. }\end{array}$ \\
\hline 14. & $\begin{array}{l}\text { Clients always wished for the presence } \\
\text { of internship students as their } \\
\text { counselor. }\end{array}$ \\
\hline
\end{tabular}

Negative transference symptom is the condition when client accuses the counselor ignores him/her and does something negative. Questions about negative transference symptom are listed in the following table.

\section{Table 2}

\section{Negative Transference Symptoms}

\begin{tabular}{r|l}
\hline No. & \multicolumn{1}{|c}{ Transference } \\
\hline 01. & $\begin{array}{l}\text { Individual counseling with internship } \\
\text { students tends to rise clients problem } \\
\text { because they want do it like their } \\
\text { parents. }\end{array}$ \\
\hline 02. & $\begin{array}{l}\text { Clients try to switch the questions or to } \\
\text { change the topic of discussion during } \\
\text { the individual counseling with } \\
\text { internship students because of } \\
\text { disbelieve. }\end{array}$ \\
\hline 03. & $\begin{array}{l}\text { Clients feel afraid and beware on the } \\
\text { notice of Internship students to have } \\
\text { counseling because they afraid of }\end{array}$ \\
\hline
\end{tabular}

\begin{tabular}{|c|c|}
\hline & secret revealed. \\
\hline 04. & $\begin{array}{l}\text { Clients have low motivation to discuss } \\
\text { their personal problem during the } \\
\text { counseling with internship students } \\
\text { because they do not look professional. }\end{array}$ \\
\hline 05. & $\begin{array}{l}\text { Clients think that internship students } \\
\text { are more concern to their duties than } \\
\text { the clients' need for counseling }\end{array}$ \\
\hline 06. & $\begin{array}{l}\text { Clients do not believe fully to } \\
\text { internship students in counseling their } \\
\text { problem because the internship } \\
\text { students cannot be trusted. }\end{array}$ \\
\hline 07. & $\begin{array}{l}\text { Clients are not focus during the } \\
\text { counseling because internship students } \\
\text { have unpleasant behavior. }\end{array}$ \\
\hline 08. & $\begin{array}{l}\text { Clients distrust on the internship } \\
\text { students' capability and ability. }\end{array}$ \\
\hline 09. & $\begin{array}{l}\text { Clients test the internship students' } \\
\text { competence in conducting personal } \\
\text { counseling, so they pretend to have } \\
\text { counseling with the internship } \\
\text { students. }\end{array}$ \\
\hline 10. & $\begin{array}{l}\text { Clients reject to have counseling with } \\
\text { internship students. }\end{array}$ \\
\hline 11. & $\begin{array}{l}\text { Clients make up reasons not to have } \\
\text { counseling with internship students }\end{array}$ \\
\hline
\end{tabular}

The questionnaire is the combination between positive and negative transference. Respondents answered with choices: always, often, sometimes, rarely and never. Than the answer will scored as table 3 .

Table 3

\section{Score of Transference Positive and Negative}

\begin{tabular}{c|l|c|c|c|c|c}
\hline \multirow{2}{*}{ No } & Trans- & \multicolumn{5}{|c}{ SCORE } \\
\cline { 2 - 7 } & ference & $\mathbf{A}$ & $\mathbf{O}$ & $\mathbf{S}$ & $\mathbf{R}$ & $\mathbf{N}$ \\
\hline 01. & Positive & 5 & 4 & 3 & 2 & 1 \\
\hline 02. & Negative & 1 & 2 & 3 & 4 & 5 \\
\hline
\end{tabular}

Transference positive number of scores is $76-125$, while negative transference is $25-$ 75.

\section{Counter-transference}

15 item was next constructed, utilizing 1). items taken intact from counter transference identification 2). unidentification. 
Table 4

The Items for Identification Types of Counter-Transference

\begin{tabular}{l|l}
\hline No & \multicolumn{1}{|c}{ Items } \\
\hline 1. & $\begin{array}{l}\text { Assumes that clients are brother or } \\
\text { sisters or relatives. }\end{array}$ \\
\hline 2. & Tries to please the clients. \\
\hline 3. & Give empathy to clients' problems. \\
\hline 4. & $\begin{array}{l}\text { Wants to have another relation outside } \\
\text { the counseling session in the school. }\end{array}$ \\
\hline 5. & $\begin{array}{l}\text { Wants to have special relationship } \\
\text { with the clients not only as client and } \\
\text { counselor. }\end{array}$ \\
\hline 6. & $\begin{array}{l}\text { Be ready as a friend for clients any } \\
\text { time they need. }\end{array}$ \\
\hline 7. & $\begin{array}{l}\text { Feels sorry for clients so freely helps } \\
\text { the clients to whatever they need. }\end{array}$ \\
\hline 8. & $\begin{array}{l}\text { Tries to give the best advice to clients } \\
\text { even if they don't need it. }\end{array}$ \\
\hline
\end{tabular}

Table 5

Unidentification of Counter-Transference

\begin{tabular}{l|l}
\hline No & \multicolumn{1}{|c}{ Items } \\
\hline 1. & $\begin{array}{l}\text { Refuses to do counseling with clients } \\
\text { who have bad attitude. }\end{array}$ \\
\hline 2. & Keeps a distance with clients. \\
\hline 3. & Drive unwanted clients away. \\
\hline 4. & $\begin{array}{l}\text { Feels dislike and worry if a client will } \\
\text { come for counseling. }\end{array}$ \\
\hline 5. & $\begin{array}{l}\text { Has a problem to give empathy for } \\
\text { clients. }\end{array}$ \\
\hline 6. & $\begin{array}{l}\text { Hates clients whose reactions against } \\
\text { counselor's principle. }\end{array}$ \\
\hline 13. & $\begin{array}{l}\text { Feel not excited and empty in } \\
\text { conducting counseling with clients. }\end{array}$ \\
\hline
\end{tabular}

Questions in the questionnaire were combined identification and dis-identification. Respondents answered with choices: always, often, sometimes, rarely and never. Than the answer will scored as table 6 .
Table 6

Score of Counter Transference Dis-Identification And Identification

\begin{tabular}{l|l|l|l|l|l|l}
\hline \multirow{2}{*}{ No } & Transfer & \multicolumn{5}{|c}{ Score } \\
\cline { 3 - 7 } & ence & A & O & S & R & N \\
\hline 1 & Positive & 5 & 4 & 3 & 2 & 1 \\
\hline 2 & Negative & 1 & 2 & 3 & 4 & 5 \\
\hline
\end{tabular}

Counter transference dis-identification number of scores is is 14-44, while identification is $>45$.

Another instrument that was used in this research is interview. Interview was given to counseling trainer (tutor) and Supervisor (from University) toward the supervision they do to internship students who do counseling practice.

\section{RESEARCH FINDINGS}

The result of transference is shown by table 7.

Table 7

\section{Result of Transference}

\begin{tabular}{|c|c|c|c|c|c|}
\hline No & Transference & Score & $\begin{array}{l}\mathbf{M} \\
(n=37)\end{array}$ & $\begin{array}{l}\text { F } \\
(n=63)\end{array}$ & Tot. \\
\hline & & & $\mathbf{F}$ & $\begin{array}{l}\mathrm{F} \\
\%\end{array}$ & $\begin{array}{l}\mathbf{F} \\
\%\end{array}$ \\
\hline 1. & Positive & $\begin{array}{l}75- \\
125\end{array}$ & $\begin{array}{l}36 \\
97 \%\end{array}$ & $\begin{array}{l}57 \\
9.4 \%\end{array}$ & $\begin{array}{l}93 \\
93 \%\end{array}$ \\
\hline 2. & Negative & $25-75$ & $\begin{array}{l}1 \\
3 \%\end{array}$ & $\begin{array}{l}6 \\
9,6 \%\end{array}$ & $\begin{array}{l}7 \\
7 \%\end{array}$ \\
\hline
\end{tabular}

The result shows that clients face positive transference $93 \%$ of total respondent, and negative transference $7 \%$. It's rarely most in male $(97 \%)$ than female $(93 \%)$. It indicates that clients feel positive transference dominantly to the university student counseling practice. The high score for items that positive transference form is clients never find reason for not having counseling with the internship students (72\%), never refuse to have counseling $(68 \%)$, never feel suspicious toward the competence of internship students in keeping the secret (56\%). (27\%) clients always fear and be careful if called for counseling by university student counseling practice because will be demolished their problem on others. 
The result of counter transference is shown by table 8 .

Table 8

The Result of Counter Transference

\begin{tabular}{|c|c|c|c|c|c|}
\hline $\begin{array}{l}\mathbf{N} \\
\mathbf{0}\end{array}$ & $\begin{array}{l}\text { Coun } \\
\text { ter }\end{array}$ & $\begin{array}{l}\text { Sco } \\
\text { re }\end{array}$ & $\begin{array}{l}M \\
(n=10)\end{array}$ & $\begin{array}{l}F \\
(n=26)\end{array}$ & Tot. \\
\hline & $\begin{array}{l}\text { Trans- } \\
\text { ference }\end{array}$ & & F $\%$ & $\begin{array}{l}\mathbf{F} \\
\%\end{array}$ & $\begin{array}{l}\mathbf{F} \\
\%\end{array}$ \\
\hline 1. & $\begin{array}{l}\text { Dis } \\
\text { identific } \\
\text { ation }\end{array}$ & $\begin{array}{l}15- \\
45\end{array}$ & $\begin{array}{l}1 \\
10 \%\end{array}$ & $\begin{array}{l}0 \\
0 \%\end{array}$ & $\begin{array}{l}1 \\
1 \%\end{array}$ \\
\hline 2. & $\begin{array}{l}\text { Identifi } \\
\text { cation }\end{array}$ & $>46$ & $\begin{array}{l}9 \\
90 \%\end{array}$ & $\begin{array}{l}26 \\
100 \%\end{array}$ & $\begin{array}{l}35 \\
97,3 \%\end{array}$ \\
\hline
\end{tabular}

Internship students faced identification counter transference $97,3 \%$ and $2,7 \%$ for disidentification. Dis identification of counter transference is rarely found. Just only one male has that symptom. All of the females have identification form.

The form of identification counter transference which mostly felt are students never extrude clients whom they do not welcome (97\%), always give empathy to clients' problems (83\%), always try to be kind to the clients $(81 \%)$, never reject counseling to the trouble client $(78 \%)$. Low dis-identification is shown to $6 \%$ internship student who always dislike and worry before having counseling practice.

Supervision format that is done by supervisor (university teacher) and tutor (high school teacher) is by conducting regular meeting once a month and by following up counseling result and written report. A professional discussion is conducted to discuss problems faced by internship students.

\section{CONCLUSION}

The results of this study offer additional support for internship students who practice counseling in senior high school. The researcher concludes that clients feel positive transference dominantly while internship students face identification counter transference. This condition affects the cooperation to gain the counseling goal. The research answers that internship students do not need to have negative thinking of being rejected by the clients. It is suggested to have analysis on training model to overcome transference and counter transference issues on counselor.

\section{REFERENCES}

Bernard, J. M., \& Goodyear, R. K. (2004). Fundamentals of clinical supervision (3rd ed.). Boston: Pearson Education.

Borders, L. D. (1991). Supervision does not equal evaluation. School Counselor, 38 (4), 253-255.

Gamsky, N.R and Farwell. (1966) Counselor verbal behavior as function of client hostility.J.Counsel.Psyshol $13 . \quad 184-$ 1900.

Hadley, S., and Strupp, H. (1976) Contemporary views of negative side effects in psychotherapy. Archieves of general Pschiatry 33.

Herbert, J. (2004a). Clinical supervision in rehabilitation settings. In F. Chan, N. L. Berven, \& K. R. Thomas (Eds.), Counseling theories and techniques for rehabilitation health professionals (pp. 405-422). New York: Springer Publishing.

Herbert, J. (2004b). Clinical supervision. In T. F. Riggar\& D. R. Maki (Eds.), Handbook of rehabilitation counseling (pp. 289-304). New York: Springer Publishing.

Irmo Marini, Mark A. Stebnicki. (2009). The Professional Counselor's Desk Reference, New York, Springer Publishing Company.

Lawrence M. B. (1982). Therapeutic Psychology Fundamental of Counseling and Psychotherapy. New Jersey: Prentice-Hall,Inc. 
Lum, C. (2007). Licensure requirements for professional counselors: A state-by-state report. Alexandria, VA: American Counseling Association.

Magnuson, S., Norem, K., \& Wilcoxon, A. (2000). Clinical supervision of prelicensed counselors:

Recommendations for consideration and practice. Journal of Mental Health Counseling, 22 (2), 176-188.

Maki, D. R., \&Delworth, U. (1995). Clinical supervision: A definition and model for the rehabilitation counseling profession. Rehabilitation Counseling Bulletin, 38, 282-294.

Page, B. J. (1994).Post-degree clinical supervision of school counselors. School Counselor, 42, 32-40.

Pearson, Q. M. (2000). Opportunities and challenges in the supervisory relationship: Implications for counselor supervision. Journal of Mental Health Counseling, 22, 283-294.

Rita Schellenberg. (2008). The New School Counselor, Strategies for Universal Academic Achievement, America, Rowan \& Little Field Education

Roberts, E. B., \& Borders, L. D. (1994). Supervision of school counselors: Administrative, program and counseling. School Counselor, 41, 149-157.

Rogers,C.R. (1951). Client-centered therapy. Boston: Houhton Mifflin.

Samuel T.G. (2012). Counseling: $a$ Comprehensive Profession, sixth edition, New Jersey, pearson Education, Inc.

Thielsen, V. A., \& Leahy, M. J. (2001).Essential knowledge and skills for effective clinical supervision in rehabilitation counseling. Rehabilitation Counseling Bulletin, 44, 196-208. 